\title{
Correction to: Findings from a novel and scalable community-based HIV testing approach to reduce the time required to complete point-of-care HIV testing in South Africa
}

\author{
${\text { Tonderai Mabuto }{ }^{1 *} \text {, Geoffrey Setswe }}^{1,2}$, Nolundi Mshweshwe-Pakela ${ }^{1,3}$, Dave Clark ${ }^{1,4}$, Sarah Day ${ }^{5}$, \\ Lerato Molobetsi ${ }^{5}$ and Jacqueline Pienaar ${ }^{5}$
}

Correction to: BMC Health Serv Res 21, 1176 (2021)

https://doi.org/10.1186/s12913-021-07173-x

Following publication of the original article [1], an error was identified in the Results section of the Abstract.

The updated Results is given below and the changes have been highlighted in bold typeface.

From 19 November 2019 to 20 December 2019, the intervention team tested 7,403 clients, and the SOC team tested 2,426 clients.

The original article [1] has been corrected.

\begin{abstract}
Author details
'The Aurum Institute NPC, 29 Queens Road, Parktown, Johannesburg 2193, South Africa. ${ }^{2}$ University of South Africa, Preller St, Muckleneuk, Pretoria, South Africa. ${ }^{3}$ The University of the Witwatersrand School of Public Health, 60 York Rd, Johannesburg, South Africa. ${ }^{4}$ Vanderbilt University, 2201 West End Ave, Nashville, TN, USA. ${ }^{5}$ The Centre for HIV-AIDS Prevention Studies, 25 St Johns Road, Houghton Estate, Johannesburg, South Africa.
\end{abstract}

Published online: 22 November 2021

\section{Reference}

1. Mabuto, et al. Findings from a novel and scalable community-based HIV testing approach to reduce the time required to complete point-of-care HIV testing in South Africa. BMC Health Serv Res. 2021;21:1176.

The original article can be found online at https://doi.org/10.1186/s12913021-07173-x

* Correspondence: tmabuto@auruminstitute.org

'The Aurum Institute NPC, 29 Queens Road, Parktown, Johannesburg 2193, South Africa

Full list of author information is available at the end of the article

(c) The Author(s). 2021 Open Access This article is licensed under a Creative Commons Attribution 4.0 International License, which permits use, sharing, adaptation, distribution and reproduction in any medium or format, as long as you give appropriate credit to the original author(s) and the source, provide a link to the Creative Commons licence, and indicate if changes were made. The images or other third party material in this article are included in the article's Creative Commons licence, unless indicated otherwise in a credit line to the material. If material is not included in the article's Creative Commons licence and your intended use is not permitted by statutory regulation or exceeds the permitted use, you will need to obtain permission directly from the copyright holder. To view a copy of this licence, visit http://creativecommons.org/licenses/by/4.0/. The Creative Commons Public Domain Dedication waiver (http://creativecommons.org/publicdomain/zero/1.0/) applies to the data made available in this article, unless otherwise stated in a credit line to the data. 